\section{BACKPACKS - LUMBAGO AFFECT ADOLESCENT AND CHILDREN: A REVIEW}

\section{ABSTRAC}

OBJECTIVE

Occurrence of Low Back Pain (LBP) at an early age, the associated causal factors and resulting consequences in adulthood have been an area of interes with PRISMA was performed the globe. A systemafic review in accordance Whe pe carying heary backpacks as a risk factor among various others for developing mechanical low back pain among school going children.

METHODS

An electronic search of databases from 2000 to 2013 was caried out. The adolescents aged 9-18 years as main outcome. Our analysis was conducted on prevalence rates and associated risk factors.

RESULTS

The results of the review revealed mostly the outcome measure based upon prevalence, risk factors of mechanical LBP and the association with backpack. the use of gints and children reported higher prevalence. The review reported factors and physical inactivity. Only 1 study outlined incorrect posture and omalies as the resulting cause.

CONCLUSION

is found between heavy backpack and childhood LBP. The review exhibits a higher prevalence with increasing age.

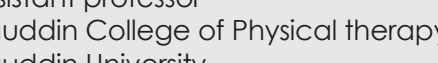

\section{Mehek Qamar}

Ziauddin College of Physical Therapy auddin University

\section{Amna Aamir Khan}

Assistant professor akhan39@caledonian.ac.uk

Muhammad Nadeem

Department of Computer Science Sir Syed University of Engineering \& mnadeem79@gmail.com

Navaid-us-Saba

Senior Lecturer

Ziauddin College of Physical therapy Ziauddin University

[Qamar $M$, Khan AA, Nadeem $M$, Navaid-us-Saba. Backpackschildren: A Review. Pak. j. rehabil. 2013:2(2):3-9

\section{INTRODUCTION}

Low Back Pain (LBP) is a physical and psychological the lower margins of the 12 thit rib to the region between one of the most frequent health concern encountered both by adults and children'1.3.7. Previously, occupation was considered as a prerequisite of LBP to affect adults and old age, but a presty chile of $L B$

Generally, the two most common identified groups of LBP are Mechanical Low Back Pain ${ }^{3}$ (MLBP) that NMLBP) characterized by specific low back pain. MLBP is the leading cause among sufferers ${ }^{3}$. It consists of no underlying pathology or structural anomaly of the back. Spinal joints, vertebrae and soff tissue surrounding the conditions such as spondylolisthesis, kyphosis and scoliosis $s^{3}$. Furthermore, epidemiological studies of past 20 years concluded that, the back pain in children falls mainly deformity or underlying pathologys.

LPP initiates during childhood ${ }^{2}$ and constitutes a chie health issue globally occurrence $^{10}$ specifically among early teenagers ${ }^{5,1}$ interestingly, children experience at least one episode of LBP by the time they reach the age of 14-17 and 5-19\%

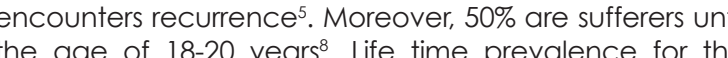
the age of 18 articular age group is estimated to be $13-51 \%$ and point prevalence as $1-33 \%$. The subject is of an interest to researchers currently, because LBP at an early age leads o persistent pain in adulihood. Patients at age 14 are cause of LBP in children is muscle sprain and strain, tha occurs while playing, falling or carrying a heavy schoo being characterized into the following four broadly psychological, physical, lifestyle and school related actors?.

Considerable research studies conducted to determine in various countries of the world identify heavy back pack ${ }^{37.121218}$ as one of the risk factors among many other or developing LBP at a younger age8,14. The load carrie average maximum is $11.5 \mathrm{~kg}$ weekly $8^{8}$. This heary $\mathrm{kg}$ an cal load is potentially harmful since it causes negative effects on the posture 11,12,14.18, development of spine ${ }^{19}$ and may result in structural injuries $1{ }^{1,14}$ to the child in addition to pain. The in hildren less than 15 years as the proportion of their body size, that is, comparatively smaller'. The ecommended back pack load bracket is $10-15 \%$ of the

According to a meta-analysis conducted by Damian ef
al on global prevalence of $L B P$ in June 2012 , the overa mean prevalence was found to be $31.0 \%$, whereas annual prevalence being $38.0 \%$ and the mean poin BP was highest among temales and individuals aged between 40-80 years. The prevalence among adolescen population was also shown to be high. If continued to predominantly among females $23.361,1,1,320222$, The prior onse onset of puberty in girls is the suggested cause ${ }^{20}$. In contrast to the studies conducted in other parts of the observed in Pakistan ${ }^{20}$. The results of mean lifetime weren er's expectation. The scores were affected specifically by studies conducted in Pakistan, China, Nepal, and Cuba, representing a low and middle income economic BPP in the above mentioned developing countries Higher tevel of exercise and pain threshold with shorter height was less accessible to industrial insurance while comparwas less accessibes to ind ustial insurance whe comparmethodological factors such as survey planning population, gender and barriers to publishing studies may also have influenced the final results

The purpose of this research is to systematically review,

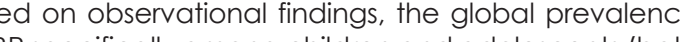
males and females). To determine the causes and rist factors associated with LBP in children of ages $9-18$ years. To describe whether carrying heavy back packs is a
significant risk factor in causing LBP among school going children or not.

METHODS

col and Registration

his systemic review has been written in accordance with PRISMA statement. The PRISMA check list can be cessed by visiting www. prisma-statement.or

Eligibility Criteria

meet the following criteria

The studies had to Teservational research any prevalence rates of low back pain among children? 9 years and adolescents $\leq 18$ years, causal or risk factors for non-specific LBP among children, associated
significance of backpack carriage and weight of backpack to LBP in children. 2. Sample size of minimum 25, both gender included. Updated research carried out between 2000 to
3.
October 2013, published in national and international journals. Studies written in English Language. 5. Experimental research studies such as case controls, randomized controlled thals, elinical trias were

Any studies related to LBP in adults, specific LBP, published in any other language than English, conducted
on single gender, above or below the specified age group, outside the time range provided, incomplete rom the review.

Information Sources
NCBI, BMJ, Medline, EurMed, Eurspine, Biomed central, the databases searched from 2000-2013. The key words such as low back pain, school, children, adolescents, backpacks, mechanical low back pain and heavy research studies and systematic reviews on $L B P$ among children and adolescents were sought.

Search

One of the full search strategies of the database, JCE 
search on web address http: // $/$ ww.jclinepi.com/ for LBP
among children and its association with back pack carriage was done using the following item

Back pain among children

Low back pain in adolescents

Low back pain in children and adolescents

Back pain in children due to back pack

Systemic review of ack pain among children Prevalence of low back pain in Pakistan Prevalence of low back pain in children Prevalence of low back pain among children

Low back pain in Pakistani children Risk factors of low back pain in children
Effects of bag pack use in children

Study Selection

An electronic search of 248 databases was initially performed by a single reviewer using the above given keywords. Research articles were rejected if the main outcome measure was not LBP among children. Base
upon the screening, 162 abstracts that did not meet the selection criteria were excluded, that is, LBP studies on adults, experimental trials, articles published in language other than English, parficipants involving single gender or of age oubide the given range, and studies involvin extracted for a closer inspection by two reviewers. Finally. 18 full text articles fuffiling our selection criteria were included.

Data Extraction and Analysis

Each article's year of publication, the number of participants, the first author, the country in which the aleCSS, cohort=CS epide, study type (Cross sectionresearch, conclusion (describing the outcomes esearch and its relation to LBP; risk factors for LBP: significance of backpack or its weight in causing LBP was

Risk of Bias in Individual Studies

Moderate risk of bias may be present in the review. The outcomes were reported and tabulated by a single of few research studies might slightly affect the overall

Synthesis of Result

bata was gathered and its summary presented in a different countries of the world Frequency of articles reporting prevalence rates of LBP, positive relationship of physical inactivity and other risk factors associated with

udy Selection

\section{RESULTS}

media 162 were withdrawn in on the basis of irrelevance to the research topic. A further of 55 articles from 82 were excluded due to the following reasons. sample inclusive only abstracts were available, research studies were RCTs, studies published in language other than English, sample inclusive of single gender. After 27 remaining articles suitable for inclusion, 9 were not available or they did not meet the selection criteria. Finally, a total of 18 articles were included consisting of 4 enidemiological1425, 5 systemic meta analysis
Computerized search of

databases $n=244$ citations

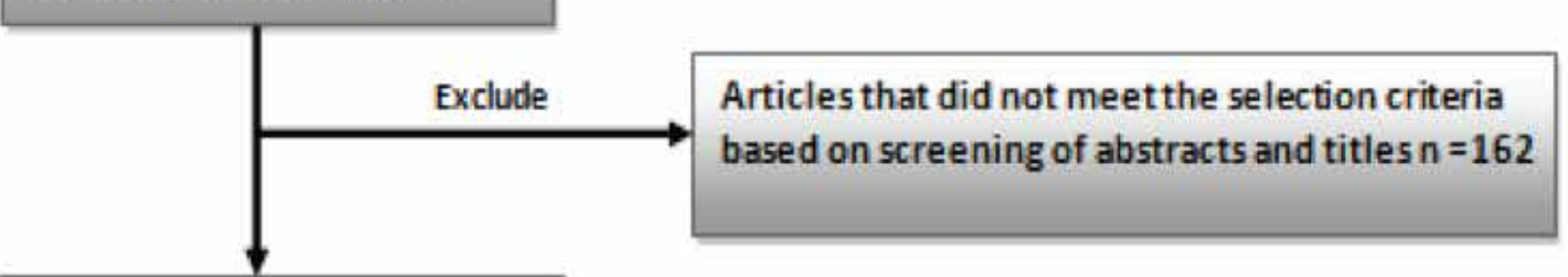

Abstract/articles retrievedfor

closer inspection by single

reviewer $n=82$

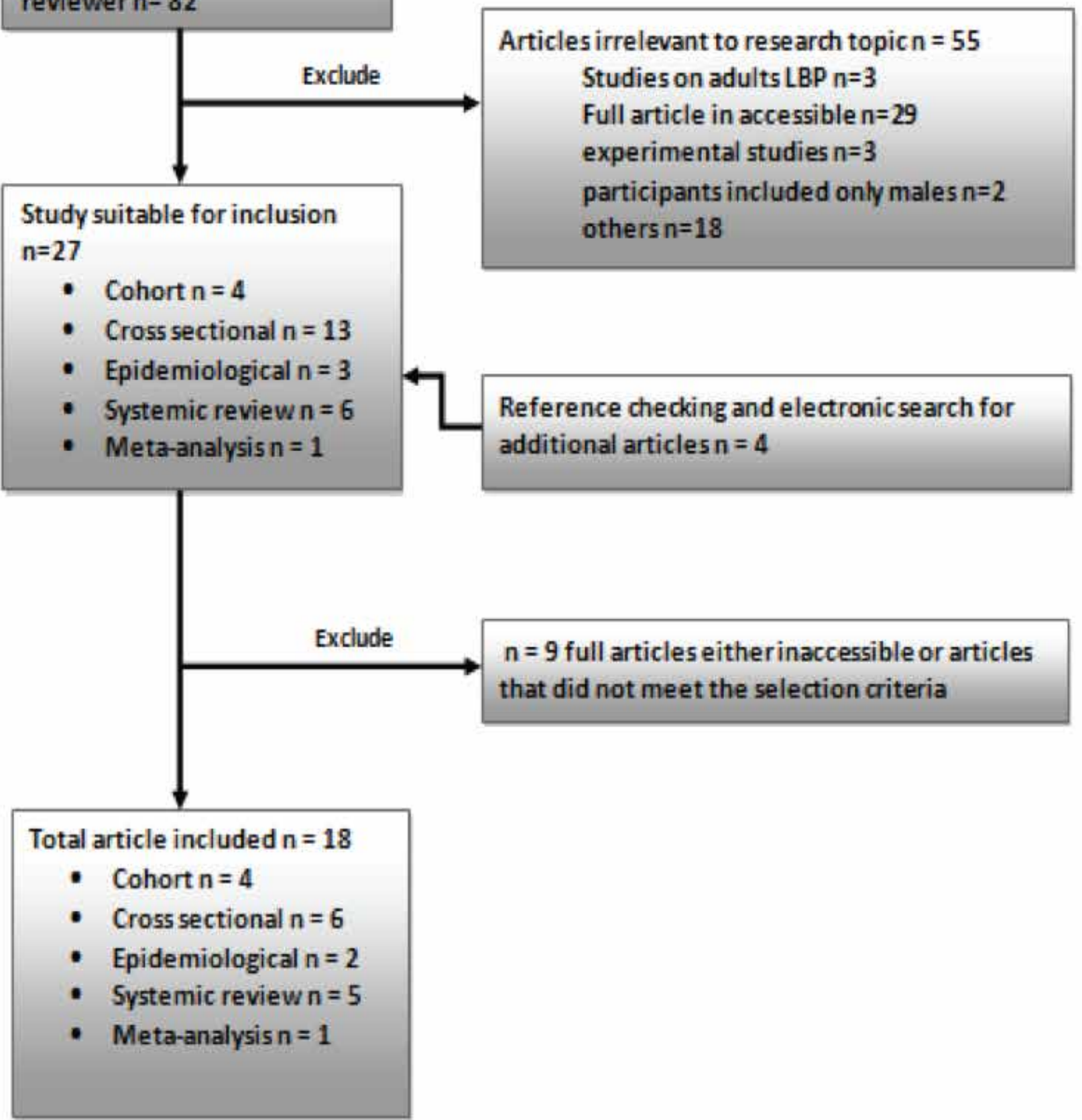




\begin{tabular}{|c|c|c|c|}
\hline Author & Objective & Results & Conclusion \\
\hline $\begin{array}{l}\text { Calvo-Munzo I } \\
\text { et al, } 2013\end{array}$ & $\begin{array}{l}\text { Prevalence rates of LBP } \\
\text { in children and } \\
\text { adolescents }\end{array}$ & $\begin{array}{l}59 \text { articles included. } \\
\text { Mean point prevalence } \\
=0.120 \text { life time prevalence } \\
\text { Mean life } \\
=0.399\end{array}$ & $\begin{array}{l}\text { Lifetime prevalence increased } \\
\text { with the mean age of } \\
\text { participants. }\end{array}$ \\
\hline $\begin{array}{l}\text { Hoy D et al, } \\
2012\end{array}$ & $\begin{array}{l}\text { Global prevalence of } \\
\text { LBP. }\end{array}$ & $\begin{array}{l}\text { Highest prevalence among } \\
\text { females. } \\
\text { Point prevalence }=11.9 \pm 2.0 \% \\
1 \text { month prevalence }=23.2 \\
\pm 2.9 \%\end{array}$ & $\begin{array}{l}\text { Global prevalence of LBP } \\
\text { increases with increasing age. }\end{array}$ \\
\hline $\begin{array}{l}\text { Jones GT et al, } \\
2005\end{array}$ & $\begin{array}{l}\text { LBP epidemiology, } \\
\text { predisposingfactors. } \\
\text { Relation of LBP in } \\
\text { childhood to LBP in } \\
\text { adulthood. }\end{array}$ & $\begin{array}{l}\text { Lifetime prevalence }=70-80 \% \\
\text { Higher Pain prevalence in girls }\end{array}$ & $\begin{array}{l}\text { Significant factors are } \\
\text { Psychological and psychosocial } \\
\text { Juvenile LBP is mild and } \\
\text { mechanical in nature. }\end{array}$ \\
\hline $\begin{array}{l}\text { Cottalorda J } \\
\text { et al, } 2004\end{array}$ & $\begin{array}{l}\text { Relationship between } \\
\text { backpack weight, LBP, } \\
\text { structural deformities }\end{array}$ & $\begin{array}{l}\text { Prevalence of mechanical LBP } \\
\text { increases from }<10 \% \text { to } 50 \% \text { in } \\
\text { preteens till } 15 \text { or } 16 \text { years age } \\
\text { in females. } \\
\text { A back pack weight of } \geq 10 \mathrm{~kg} \\
\text { children (12 years of age) } \\
\text { causes LBP }\end{array}$ & $\begin{array}{l}\text { The weight of Back pack mus } \\
\text { be } \leq 10 \% \text { of body weight. } \\
\text { Children: Carrying heavy schoo } \\
\text { bags, muscular imbalance } \\
\text { trauma, and increased BMI } \\
\text { were noticed. }\end{array}$ \\
\hline $\begin{array}{l}\text { Trevelyan FC } \\
\text { et al, } 2004\end{array}$ & $\begin{array}{l}\text { Risk factors associated } \\
\text { with LBP in children } \\
\text { aged 11-14 years in } \\
\text { school }\end{array}$ & $\begin{array}{l}\text { Risk factors of LBP in School } \\
\text { girls included family history } \\
\text { anthropometric parameters, } \\
\text { spinal mobility, physical and } \\
\text { sports activity, sedentary } \\
\text { posture in classroom }\end{array}$ & $\begin{array}{l}\text { Intervention \& epidemiologica } \\
\text { studies should be addressed, if } \\
\text { the musculoskeletal problems } \\
\text { in school children are } \\
\text { identified. }\end{array}$ \\
\hline $\begin{array}{l}\text { Cardon G et al, } \\
2004\end{array}$ & $\begin{array}{l}\text { Preventive measures } \\
\text { and modifiable } \\
\text { predisposing factors of } \\
\text { LBP in teenagers }\end{array}$ & $\begin{array}{l}\text { Factors related to LBP: } \\
\text { smoking, psychosocial factors, } \\
\text { working off school hours, and } \\
\text { eating habits. } \\
\text { Factors not related to LBP: } \\
\text { BMl, muscle strengthening, } \\
\text { and physical fitness. }\end{array}$ & $\begin{array}{l}\text { Little evidence supports that } \\
\text { the use of heavy backpack } \\
\text { causes LBP. Whereas, factors } \\
\text { like, mobility and flexibility, } \\
\text { sedentary activities of schoo } \\
\text { children, remained unclear }\end{array}$ \\
\hline
\end{tabular}

\section{Study Characteristics
a) Participants:}

This review comprises of participants aged between 9
and 18 years (mean 13.5 years) of both genders. The and 18 years (mean 13.5 years) of both genders.
particular age group being selected since LBP in children is specifically related to possible LBP in adulthood $1,1,1$, with $50 \%$ of individuals experiencing LBP till reaching 188 . There is a rapid growth in LBP with increasing age $29,1,1,19,2$
principally in females age of 12 years are referred to as children and considered adolescents if their age is between ages 12 to 18 years6. Psychologicall1,17.2232328 states such as anger
iritation, depression, school related and other mental
stress are all related to cousing stress are all related to causing LBP among childrent, $1^{28}$. A

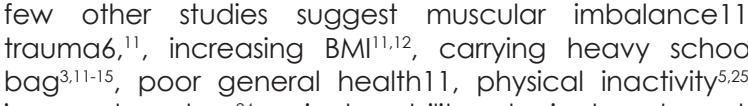
bag
incorrect posture $2^{42}$, spinal mobility, physical and sports activity, duration and posture while sitting in school ${ }^{24}$
muscle strengthening, smoking, eating habitst as muscle strengthening, smoking, eating habits"27 as
potential risk for causing LBP. There was conflicting evidence describing different significant causal factors b) Sample Size:
All studies included in the review contained sample size
greater than 25 .

\section{Predisposing Risk Factors:
c)}

Risk of Bias within Studies

studies conducted in separate countries of the world and disparate research design, each with different objectives and unique outcomes. Observation of such diverse research studies minimizes
the effect of bias within the selected studies and their he effect of bias within the selected studies and their
outcome measures. Synthesis of Results

After close inspection of the selected articles, 18 were ncorporated in this review. Consisting arricles were 6
cross-sectional studies, 4 cohort, 2 epidemiological, 5 systemic reviews and 1 meta-analysis.

7 out of 18 studies demonstrated high prevalence rates of
LBP23,5.1315,522.24 especially in girls. 6 showed a positive correlation of LBP with heavy backpack use in school
children $^{3.111 .131 .1526}(2$ systemic reviews, 2 cross-sectional studies, 1 cohort and 1 epidemiological study supported heavy back pack use for causing LBP among children). A Urther $3(2$ cohort, 1 systemic review) emphasized mento
health profile as the leading cause of LBP among young individuals'17.22.23. I cohort study proposed incorrect posture during sleep and structural deformities as reason
for LBP and 2 other, a case-control 25 and cross-section study related LBP to reduced physical activity in study related.
children $^{5,25}$.

\section{DISCUSSION}

Among the included reviews given above in table 1 according to the most recent review article on $L B P$
prevalence rates of adolescents and children, the resu values were shown as mean point prevalence= 0.120 mean period prevalence $(12$ months) $=0.336 ;$ mean
period prevalence at one week $=0.177$ and mean life time prevalence $=0.399^{2}$, thus affirming the proposed assumption and highlighting the fact that LBP in this particular group persists as a global health issue as well20. The authors' comparison of their work with the previous ones on our specific subject22.20. They sugested standardization of LBP definition to aid in upcoming subsequent reviews allowing additional collation between countries and an enhanced understanding or his particular musculoskele the number of studies, a major drawback is its type, tha is, major of studies belonging to the category of being cross-sectional. As a result, it becomes difficult to differentiate etiology from prognosist

The average time a patient spends suffering LBP is greater than three days with a pain score of $4-6$ on VAS score indicating moderate intensity pain. This certainly point
out the considerable seriousness of LBP symptoms, given the higher pain duration and intensity. Moreover, sufferers reporting pain radiating down the leg also show a greater
degree of disability, hence, causing a significant
disturbance in their activities of daily living. Low back health awareness and education is substantial to reduce he effects and prevent LBP altogethert.2.

For the formation of constructive health education or health policy programs directed towards our targeted heir health behavior, and the factors influencing them Modification of risk factors such as school bag weight' $a$ physical inactivity25 might prove beneficial, but it is essen-
tial to create awareness regarding maintenance ial to create awareness regarding maintenance of and practice good ergonomics so as to minimize its occurrence. Irrespective of the cause, $94 \%$ of the adolescent LBP sufferers ${ }^{21}$ experience some kind of disability

\section{Summary of Evidence}

The supporting literature was from research carried out in 8 high quality studies, Diversity of the included enidence proved extremely beneficial. The evaluation of results confirmed the hypothesis that, there is a strong association between mechanical low back pain and students carying hefty schoolbags erm and long term. One of the most important finding was the high vulnerability of females to this particular medical conditons. The proposed reason stress and strain to their soft bones at growing age,
carrying heavier school bags in comparison with their male counter parts of same $a^{8} e^{8}$ and they being more from increased parental role model than boys'9. Apart affirm psychological and psychosocial factors as an equally predominant cause of LBP in $9-18$ years old

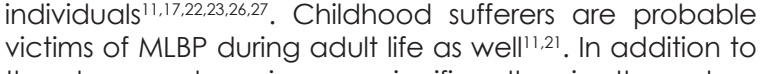
the above, advancing age significantly raise the potenemained more or less the same and the increase in pain intensity with age was to a lesser extent 19. The elucidated tion if possible. It is fairly substantial to highlight the issue and create awareness among layman.

The most successful strategy identified to promote the ed at school manifest their compound effect on health problems reduction, improve efficacy of education system and enhance social development. Various health to greatly reduce the incidence of $L B P$ despite its multiple causes. WHO enumerated four key elements in the accomplishment of the goal: a) promoting a healthy environment, b) health education, c) opportunities for offering programs for social

At the moment, limited research is available to evaluate the effectiveness of preventive approach whether at group4. Furthermore whether psychosocial risk factors which also greatly contribute to LBP21,22 in school children are modifiable remains still a question. A distinction required $d^{27}$.

\section{Study Limitations}

Antitilly, the article search and selection only included full reported publications in English Language. Research
refially, he articte studies published in any other language were discarded.
The heterogeneity of included studies resulted in variable The heterogeneity of included studies resulted in variable outcomes (variation in sample size, resulting LBP preva-
lence rates, and variety of associated risk factors). Thus,

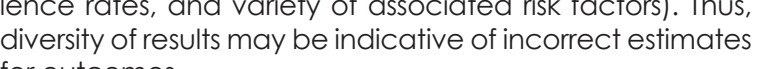
or outcomes.

\section{CONCLUSION}

As a strategy to reduce the incidence of LBP at an early age, the weight of the backpack carried daily to school
must not exceed $10 \%$ of the child's body weightl1.14. Despite the wide variation in studilies, the outcomes showed high prevalence rates of LBP. Mental health of area for further investigation. The research on our topic must be carried out in Pakistan as well.

\section{REFERENCE}

[1] Onofrio AC, Silva MC, Domingues MR, Rombaldi AJ, Southern Brazil: prevalence andolociocied foctors. Eur Spine J 2012:21 (7):1234-1240,

[2] Calvo-Munoz I, Conesa AG, Meca Js. Prevalence of low back pain in children and adolescents: a
meta-analysis. BMC Pediatrics

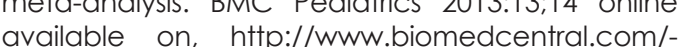
content/pdf/1471-2431-13-14.pdf 
[3] Dhanesh KKU, Putti BB, Manjula S. Prevalence of mechanical low back pain in school children of adolescent group
2012;4(3):213-218.

[4] Jones MA, Stratton G, Reilly $T$, Unnithan VB. A quence in children. Health educ Res 2004;19(3):284-289.

Thack 2008:17(S3):373-379.

[6] Sato T, Ito T, Hirano T, Morita O, Kikuchi R, Endo N, et al. Low 2008:17(11):1441-1447.

Negrini S, Carabalona R, Sibilla P. Backpack as a daily load for school children. Lance $1999,354(9194) .1974$.

back pain in schoolchildren: the role of school bag weight and carrying way.
J

9] Habybababady RH, Ansari-Moghaddam A, Mirzaei R. of back care education on knowledge and behavior of elementary school children. J Pak Med Assoc 2012;62(6):580-584

10] Saudi school bols backpack; how much load do Med J 2006;27(10): :1567-1571.

[11] Cottalorda J, Bourelle S, Gautheron V. Effects of (in Children.

S. Back Problems Due To Heavy Backpacks in school Children.-IOSR-JHSS 2013:10(6):22-26.

[13] Sheil-Neiss Gl, Kruse RW, Rahman T, Jacobson LP. 2003.28(9):922-30.

14] Choy JAG, Flores FEG, Merinos O, Cobos FJS, Hernandez MFC, Ramirez PH, et al. An assessment the anthropometric and external variables that school Students. Ergonomia Occupationa 2012:5:45-51.

[15] Negrini $S$, Politano E, Carabelona R, Tartarotti L clinical and social importance and efficacy of community-based educational intervention.
Eur Med Phys 2004:40(3):185-190.

Negrini S, Negrini A. Postural effects of symmetrica and asymmerrical loads on the spines of schoo

JWR, Postma DS, et al Mussann H, Picavet J, Twisk Among 11-Year-Old Children and Associated

Factors Am J Epidemiol 2011,174(8).877-884.

effects of load cariage on young people systematic review. BMC 2003:4:12

[19] With B, Knecht C, Humphreys K. Spine day 2012: spinal pain in Swiss school children-epidemiology

[20] Hoy D. Bain C. Williams C, March L Brooks P. Blyth F et al. A Systematic Review of the Global Prevalence of Low Back pain. Arthritis \& Rheumatism

21] Watsona KD, Papageorgioua AC, Jonesa GT
Taylora S Symmons DP Silman AJ, et al Low back pain in school children: occurrence and character-

istics. Pain 2002;97(1-2):87-92.

22] Jones GI, Mactarlane GJ. Epidemiology of low Child 2005;90:312-316

[23] Jones GT, Watson KD, Silman AJ, Symmons DPM Macfarlane GJ. Predictors of Low Back Pain in British Cohot Study. Pediatics 2003:111:822.

24] Kovacs E, Oliver-Frontera $M$, Plana $M N$, Royuela Muriel A, Gestoso M. Improving School children 's Knowledge of Methods for the Prevention and 2011:36(8):505-512

[25] Jones MA, Stratton G, Reilly $T$, Unnithan VB. Biological risk indicators for recurrent non-specific low back pain

26] Tevelyan F

-children-Where 5 s. Back pain in schoo 2006:37:45-54.

[27] Cardon $G$, Balague $F$. Low back pain prevention's Spine J 2004; 13:663-679.

[28] Roth-sigkeit A, Thyen U, Sto ven H, Schwarzenberge J, Schmucker P. Pain Among Children and AdolesFactors. Pediatrics 2005:1512) e152 a2

\section{EFFECTS OF SHORT WAVE DIATHERMY AND HOT PACK WITH BACK STRENGTHENING EXERCISES IN THE MANAGEMENT OF ACUTE LOW BACK PAIN}

\section{ABSTRACT}

Acute back pain is the fifth most common reason for visiting the physicians and practitioners. It is one of the most common musculoskeletal problems in the society. This research has been conducted on experimental method by using
sample size of 60 patients including both the genders. The participants have been selected from the OPD of physical therapy and rehabilitation of the tertiary care hospital. 60 patients was divided into two groups where Group A was treated with hot packs at low back for 25 minutes with low back strengthening exercises and whereas Group B was treated With SWD (continuous mode)

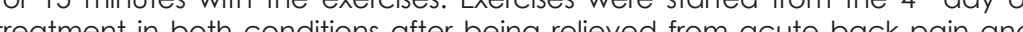
Therefore, the symptoms have been reassessed at $8^{\text {th }}$ and $15^{\text {th }}$ day of treatment. Affer analyzing the data has found that, he patients in group A trealed with quickly and efficiently than the group B treated with short wave and exercises.

Samreen Yasmeen

Ziauddin College of Physical Therapy ziauddin University samreenkamran2009@gmail.com

Syeda Amool Sakeena Rizvi Ziauddin College of Physical Therapy Ziauddin University
sakeenarizvis@gmail.com Management of Acute Low Back
Pak. j. rehabil. 2013;2(2):10-14] 